\title{
QUEEN'S
UNIVERSITY
BELFAST
}

\section{Delineating human resource management practice in domestic and foreign owned multinational enterprises in Australia}

\author{
McDonnell, A., Boyle, B., Stanton, P., Bartram, T., \& Burgess, J. (2016). Delineating human resource \\ management practice in domestic and foreign owned multinational enterprises in Australia. Asia Pacific Journal \\ of Human Resources, 54(2), 165-187. https://doi.org/10.1111/1744-7941.12092
}

\section{Published in:}

Asia Pacific Journal of Human Resources

\section{Document Version:}

Peer reviewed version

Queen's University Belfast - Research Portal:

Link to publication record in Queen's University Belfast Research Portal

\section{Publisher rights}

(c) 2015 Australian Human Resources Institute

This is the peer reviewed version of the following article: [McDonnell, A., Boyle, B., Stanton, P., Bartram, T. and Burgess, J. (2015),

Delineating human resource management practice in domestic and foreign-owned multinational enterprises in Australia. Asia Pacific Journal of Human Resources, which has been published in final form at http://onlinelibrary.wiley.com/doi/10.1111/1744-7941.12092/abstract. This article may be used for non-commercial purposes in accordance with Wiley Terms and Conditions for Self-Archiving

\section{General rights}

Copyright for the publications made accessible via the Queen's University Belfast Research Portal is retained by the author(s) and / or other copyright owners and it is a condition of accessing these publications that users recognise and abide by the legal requirements associated with these rights.

\section{Take down policy}

The Research Portal is Queen's institutional repository that provides access to Queen's research output. Every effort has been made to ensure that content in the Research Portal does not infringe any person's rights, or applicable UK laws. If you discover content in the Research Portal that you believe breaches copyright or violates any law, please contact openaccess@qub.ac.uk. 


\title{
Delineating human resource management practice in domestic and foreign owned multinational enterprises in Australia ${ }^{1}$
}

Anthony McDonnell, Brendan Boyle, Pauline Stanton, Timothy Bartram and John Burgess

\begin{abstract}
To date there is an absence of any systematic and extensive data on Australian MNEs. This research paper fills the information gap and leads to a discussion of the human resource management (HRM) practices of Australian MNEs in the global arena and whether there is a distinctive national identity associated with these practices. We report on the profile of Australian based multinational enterprises (MNEs). Drawing on a systematic database developed by the authors in 2010/11 we are able to identify the numbers of Australian MNEs and their characteristics and compare them against a representative sample of foreign-owned MNEs operating in Australia.
\end{abstract}

\section{Introduction}

There is now an impressive literature focused on the human resource management (HRM) practices of multinational enterprises (MNEs). Evidence shows that as the number of MNEs and international investment by MNEs continues to expand (UNCTAD, 2012), the MNE landscape is changing dramatically. The emergence of state owned MNEs, and MNEs from developing countries, as well as large scale MNE investment shifting into Africa, Asia and South America has challenged established paradigms. In particular, different ownership forms, different countries of origin and different countries of investment destination raise new questions for researchers and new challenges for practitioners (Akhtar et al, 2008; Bartram et al, 2015; Bischoff and Wood, 2010). This is particularly the case for Australia where there has been significant foreign investment growth from China, Malaysia, Canada and Singapore, and indeed the Foreign Investment Review Board (FIRB) has reported that China is now the major source of inward foreign investment into Australia (FIRB, 2014).

A significant focus in the HRM literature has been on the extent to which MNEs pursue global HRM approaches and the impact of home and host institutional contexts (e.g. Ferner and Quintanilla, 2002; Edwards, Sanchez-Mangas, Tregaskis, Leveque and McDonnell, 2013). This literature has explored the development and implementation of HRM practices (Edwards et al, 2013; Farndale et al, 2010; Gooderam and Nordhaug, 2010). In particular, consideration of the cultural, political and economic settings in which MNEs operate and are regulated (Bjorkman and Lervick, 2007; Hall and Soskice, 2001). The understanding of these different influences on HRM policy and practice reflects an interest in the extent to which there is a convergence or a divergence across MNEs in their HRM strategy. For example, within a single national setting where laws, culture, political economy and business regulation are similar, will we find a convergence towards the same set of best practice HRM activities regardless of the country of origin of the MNEs (Almond et al, 2005; Edwards et al, 2013)? Or will we find that there is difference that reflects the influence of the different degrees of embeddedness of the home countries institutions and practices (Almond et al, 2005; Edwards et al, 2013)? In spite of the growth in scholarship in this area, Edwards,

\footnotetext{
${ }^{1}$ The financial support of the Australian Research Council Discovery Project Scheme (DP120203071) is acknowledged. We would also like to thank the PhD students involved in the project, particularly Helen Russell and Gitika Sablok.
} 
Marginson and Ferner (2013: 548) argue that "our understanding of how MNEs operate has many gaps, and these arise from both empirical and conceptual shortcomings".

One criticism of the literature is that it has tended to be dominated by research emanating from the larger and longest industrialised economies. While there is growth in research on MNEs from the emerging economies in Asia, the Middle East and Africa (Akhtar et al, 2008; Haiying and Sien, 2014; Sidani and Al Ariss, 2014) there are fewer studies of MNEs emanating from smaller economies, especially domestically owned MNEs from such nations. Australia is a case in point. The Australian economy despite being the $6^{\text {th }}$ largest country in the world by land mass is a small politically stable economy, and can be described as a developed and modern regulated liberal market economy.

The presence of foreign owned MNEs is notable across all sectors of the Australian economy and have been the focus in papers published in leading international journals (e.g. Gooderham, Nordhaug and Ringdal, 2006; Fenton-O’Creevy, Gooderham and Nordhaug, 2007; Johnston and Menguc, 2007). However, domestically owned Australian MNEs have received considerably less attention, particularly when considering papers in international scholarly journals (McDonnell, Stanton and Burgess, 2011a). This is despite the fact that in a number of sectors (e.g. mining, banking, insurance) Australian MNEs have become significant global players over the past three decades. Dick and Merrett (2007) and Merrett (2007) highlight the fact that Australian based MNEs are a relatively recent phenomenon, only emerging in post 1980s. Merrett (2007) assesses the sector and company details of Australian MNEs and discusses those factors that have limited the development of Australian based MNEs. In 2011, the stock of Australian foreign investment abroad stood at \$1175b; the largest stocks by share are held in the USA (35\%), the UK (16\%), New Zealand (6\%) and Canada (4\%). In 2011 the top four destinations for Australian FDI were the USA (69\%), Canada (13\%) and the Netherlands and China (each 10\%). In terms of investment the top three sectors for Australian foreign investment in 2010 were mining (41\%), finance and insurance (28\%), and manufacturing (16\%) (ABS, 2011). In terms of global Australian headquartered companies BHP Billiton is ranked in the top 100 firms globally, while QBE Insurance is ranked in the top 50 financial institutions in terms of global spread (UNCTAD, 2012). In recent years Australian MNEs have been responsible for some of the largest global investments, with AMP Insurance acquiring AXA Asian Pacific for \$11.7b and BHP Billiton acquiring Petrohawk Energy for \$12.1b. In 2011 BHP Billiton was the $3^{\text {rd }}$ largest investor globally from the top 100 MNEs (UNCTAD, 2012). Thus, while Australian FDI and MNEs are increasingly important global players there has been limited research in relation to their HRM practices.

Furthermore, while there is a literature that considers foreign owned MNEs in Australia (Johnstone and Neguc, 2007; Walsh, 2001), there a lack of systematic data on their activities. Indeed McDonnell et al (2011a) highlighted the absence of any official Australian database on foreign owned MNEs. This is surprising given that such MNEs have been significant investors and employers in Australia over a long period. Official data on foreign owned MNEs is confined to the Foreign Investment Review Board which publishes an annual review of inward investment into the Australian economy (FIRB, 2014), while the Australian Bureau of Statistics (ABS) provides data on international investment (ABS, 2011). This situation is further accentuated in the case of domestic Australian MNEs for which there is no publicly available data. This makes it difficult to determine to any reliable degree the activities, HRM policies and practices of MNEs operating in Australia. 
In terms of Australian MNE operations abroad the evidence and analysis is limited to specific countries, industries, specific HRM practices or case studies (Fee, McGrath Champ, Xiu, 2011; Kulman and Hutchings, 2010; Hutchings, 1996; Tharenou and Harvey, 2010). The relatively small number and the emergence of Australian MNEs within the past 25 years (Merrett, 2007) have been factors limiting research as has the absence of any systematic and accurate data on Australian MNE operations abroad. In this paper we are not reporting on the HRM practices of Australian MNEs abroad, but their operations in Australia.

Cognisant of such limitations, this paper examines the following questions: how many Australian based MNEs are there, in what sectors are they located and what are their characteristics in terms of such conditions as sector, employee numbers and number of countries in which they operate? Do Australian MNEs have similar HRM practices to those of other host country MNEs operating in Australia? Where are these differences in the HRM policies of Australian and rest of world MNEs operating in Australia and what factors explain these differences? To address these questions we draw on our own representative sample of MNEs in Australia entailing data collected from the most senior HR practitioners in 211 firms. This paper represents a summary of the key features and covers only part of the HRM data that was collected through the survey.

\section{Should HRM in Australian MNEs be different?}

Evidence from a range of countries including Australia, (typically drawing on CRANET or the Australian Workplace Industrial Relations Survey (AWIRS) data), suggests that foreign owned MNEs are different to indigenous firms in their approaches to HRM (e.g. Walsh, 2001; McGraw, 2002, 2014; McGraw and Harley, 2003). In particular arguing that foreign firms are more innovative and formalized when it comes to HRM practices largely due to the size and complexity of international operations that results in more extensive HRM practices across all HR functions (Guest and Hoque, 1996).

Other evidence suggests that there are also differences by country of origin in relation to the sophistication of the HRM practices of MNEs. The business system of the home country of MNEs can impact on subsidiary operations (Almond et al., 2005) leading to parent country practices (within limits) being transferred to subsidiaries abroad. Differences have been long been noted across Japanese, US and German MNEs in terms of union recognition, team working, recruitment, the use of expatriate managers, performance management, reward systems and training systems (e.g. Purcell et al, 1999). However, we also know that host country business systems can also modify MNE behaviour and depending on systems of business and labour regulation and can reduce the differences by county of ownership. In other words, host business systems may moderate MNE parent country HRM practices so that there is a process of local adaptation to host country models and process (Colling and Clark, 2002; Almond et al., 2005; Edwards, Sanchez-Mangas, Tregaskis, Leveque and McDonnell, 2013). More recent evidence suggests that the growth of international best practice has led to a convergence of many HRM practices, such as individual reward and performance appraisal, not on a US norm but on a best practice MNE norm. Hence, these increasingly standardised practices are adopted by many companies and are less identifiable as American (Ferner and Almond 2013; Bartram et al 2015a; Kramar and Parry 2014). This research suggests that it is the context that often drives what companies can do or not do in the HRM domain and that companies have a range of tools at their disposal that they implement according to the host environment. 
In light of the above, would we expect the HRM practices of Australian MNEs to be different from MNEs domiciled elsewhere? Based on the varieties of capitalism literature (Hall and Soskice, 2001) for example, we would expect Australian MNEs to be similar in some respects to firms headquartered in other Anglo Saxon economies - i.e. economies with a similar liberal market system, with companies being publically listed, possessing short planning and reporting horizons; and engaging in trade union avoidance. However, the national business systems evidence suggests that key national features will be embedded within the MNE. Therefore, we could suggest that the HR practices in Australian domestic MNEs will show some variation to their foreign counterparts. This is likely to be due to Australia's industrial relations system, corporate regulation system and other workplace related legislation. Moreover, difference may be expected on the basis that Australian MNEs are typically quite a recent phenomenon and are likely to be smaller in global scale to their foreign counterparts with size often positively associated with more formal and sophisticated HRM systems.

However, we have little empirical data on which to draw out any proposition about the behaviour of Australian MNEs. In his study of the emergence of Australian MNEs Merrett (2007) uses official ABS data on foreign investment to trace the rise and spread of Australian MNE data, however, such data cannot address HRM practices. Based on a systematic literature review of research on MNEs in Australia over two decades, McDonnell et al. (2011a) highlighted the knowledge deficit on the domestic grouping of MNEs. There have been comparisons of foreign MNEs versus domestic firms but not specifically domestic MNEs. De Cieri and Dowling (1997) previously argued that small and late internationalising MNEs may have a differentiated pattern of behaviour relative to larger, more mature MNEs. Recent evidence from a comparative study conducted in Ireland, failed to find evidence that US styled, global best HR practices were the norm across other MNEs (McDonnell, Lavelle and Gunnigle, 2014).Their study which looked at Irish owned, domestic MNEs compared to foreign MNEs indicated a less formalized or sophisticated approach to HRM in domestic MNEs.

Hence, we argue that the data provided in this paper may help us to understand the current HRM practices of MNEs in Australia in both foreign owned and Australian owned companies. Before we illustrate the key results we detail the research methods that we employed, as the establishment of the MNE database was a major component underpinning the strength of our findings.

\section{Research Method and Development of the Australian MNE Data Base}

The data stems from a representative survey of HRM practices of MNEs operating in Australia. The criteria applied and the methodology that was used followed the protocols set out in the INTREPID international project assessing employment practices of MNEs across several countries (McDonnell et al., 2011b). Foreign MNEs were defined as those that employed at least 100 in their Australian operations and 500 or more employees worldwide. Australian MNEs employed 500 persons worldwide, with at least 100 of these being employed outside of Australia. The identification of a comprehensive and representative population of MNEs in Australia was not a straightforward process. This was largely due to the incomplete and inaccurate coverage of company database listings. As a result of issues surrounding the reliability and comprehensiveness of many of these databases, we constructed our own database listing using a large number of diverse sources (see McDonnell et al, 2011b for full details). 
During 2008/09 a total population of 1,008 MNEs operating in Australia was developed. From this population, a stratified random sample of 549 MNEs was selected according to country of origin and primary sector of operation. We lost 22 firms due to delisting, bankruptcy or merger by the time we were ready to undertake the survey. Consequently, we had a final sample of 527 MNEs.

The questionnaire used was adapted from comparative INTREPID studies in the UK, Canada and Ireland which was also piloted before fieldwork commenced. The questionnaire focused on the key HR areas of pay and performance management, employee representation and consultation, training and development, and employee involvement. The target respondent for the study was the most senior HR Practitioner - (e.g. HR Director, Senior/Group Head HR Manager), for the MNE in Australia. In other words, the aim was to interview the most senior HR representative able to answer specific questions on the HR practices and policies of the organisation's Australian operations. Consequently, this is an organisational level study (in cases of a MNE having more than one Australian subsidiary we spoke to the person able to answer for all).

The questionnaire was administered through a structured face-to-face interview. This administration process was selected because of its success in yielding better response rates and reducing missing data. The research team conducted the fieldwork between December 2009 and February 2011.

A total of 211 usable interviews were obtained giving a total overall response rate of 40 per cent. In terms of employee information we focussed on three groups in the Australian based operations: managers; the key occupational group, and the largest occupational group (LOG) defined as the largest non-managerial occupational group among the employees. The key group was nominated by the HR managers and was regarded as an occupational group formally viewed as vital or strategic to the Australian operations. Specifically, respondents were asked to report if a key group of employees were identified as critical to your firm's core competence and organisational learning.

We now provide some basic description of the characteristics of Australian MNEs before taking a closer look at a selection of HR practices of these firms and their foreign counterparts. The paper primarily relies on univariate analysis but we also draw on independent sample t-tests, as well as cross-tabulations using Cramer's V tests to compare foreign and domestic MNEs. The comparison refers to the HRM policies and process that apply to Australian operations. For some questions there was a focus on global operations; for example, if there was a global HRM committee. In the analysis we indicate whether we are comparing local or global operations.

\section{Results}

\section{MNEs in Australia: Numbers and Characteristics}

We first report on the numbers of MNEs in Australia. Table 1 indicates that of the population of MNEs in Australia, the domestic owned MNEs were the second largest group after the US firms. While we do not have data to compare to, the research team were surprised in terms of the numbers and their relative share. The number of Australian MNEs was almost double the third group of UK owned MNEs. 
The next set of descriptive data relates to the primary sector of the 40 Australian MNEs who took part in the survey. From Table 2 below, it is apparent that in keeping with the structure of the economy, domestic MNEs have a major presence in service sector, slightly more than the case of foreign owned MNEs. There has been significant news coverage over the past couple of years on the potential death of Australian manufacturing. This cross-sectional study shows that less than one quarter of Australian MNEs were primarily engaged in manufacturing activities.

Table 2 here

Table 3 below demonstrates that in terms of organisational structural arrangements that the majority of Australian MNEs have national subsidiary companies, and more than half have international product, regional and global business divisions. Where multiple structural forms were in existence, the international product division was most commonly regarded as being the most important structure in global operations.

\section{Table 3 here}

Other general organisational features of Australian MNEs, with foreign MNE comparators, are summarised in table 4. For example, the median number of sites of Australian MNEs is 30 and over 40 per cent of Australian MNEs operate in more than 10 countries. In terms of the median responses around one half of the Australian MNEs established international operations in the past 10 years and as such are relatively new international players. Moreover, merger and acquisition was the preferred method of establishing an overseas presence. The major ownership structure is through publicly listed and traded shares; only 15 per cent of the Australian MNEs were privately owned or public institutions. The major competitive strategy adopted is one of product customisation. Approximately 74 per cent of Australian MNEs reported that other operations of the worldwide company supply the Australian operations. Alternatively, 56 per cent noted that the components/services of the Australian operations were produced for some or all of the worldwide company's non-Australian operations. The comparison with foreign owned MNEs in Australia reveal that Australian MNEs have on average fewer employees worldwide, more employees and sites in Australia and have operations in fewer countries.

\section{Table 4 here}

\section{Human Resource Management Practices}

We now present some of the key HRM features of Australian MNEs and we highlight some of the key differences relative to foreign owned MNCs operating in Australia. Specifically, we focus on the size of the HR function, strategic HR practices, pay and performance management, training and development and employee representation.

\section{The HRM Function and Strategic HRM Practices}

In the survey respondents were asked about the number of people employed in the HRM function in MNEs in Australia. Just over 60 per cent employ between one and nine people with a little over 10 per cent of MNEs reporting a HRM function in excess of fifty people. Australian MNEs tend to have larger HRM functions but given that employment in the Australian operations of these firms are much higher than foreign firms; this is to some degree expected. Specifically, the data shows that 70 per cent of foreign MNEs have a HRM 
function employing 1 - 9 people with the equivalent figure for Australian MNEs being 25 per cent employing 1-9 persons. Almost 38 per cent of Australian MNEs have a HRM function that employs in excess of 50 staff compared to only 6 per cent of foreign MNEs who have over 50 HRM staff.

Australian and foreign owned MNEs reported similar use of strategic HRM practice. Strategic HRM can be viewed as a long-term approach to the management of employees within the organisation (Boxall and Purcell, 2008). An independent-sample t-test was conducted, on four questions which used a 5-point Likert scale, to compare the strategic HRM in the Australian operations of foreign owned MNEs and Australian owned MNEs in Australia. Findings demonstrated that there was no significant difference in HRM strategy in the Australian operations between foreign owned MNEs $(M=4.09, S D=.86)$ and Australian owned MNEs $(M=3.83, S D=1.15) ; t(209)=1.62, p=.11$ (two-tailed). There was no significant difference observed in the way HRM strategy was effectively integrated with corporate strategy in the Australian operations of foreign owned MNEs $(M=4.00, S D=.94)$ and Australian owned MNEs $(M=3.90, S D=1.03) ; t(209)=.60, p=.55$ (two-tailed). No significant difference was found in the way that HRM strategy had input-influence on corporate strategy in the Australian operations between foreign owned MNEs $(M=3.65$, $S D$ $=1.05$ ) and Australian owned MNEs $(M=3.55, S D=1.06) ; t(209)=.54, p=.59$ (twotailed). No difference was found in the way HRM practices were integrated and consistent with each other in the Australian operations between foreign owned MNEs $(M=3.88, S D=$ $.89)$ and Australian owned MNEs $(M=3.58, S D=1.08) ; t(52)=1.67, p=.10$ (two-tailed). The evidence suggests that Australian owned MNEs reported similar use of strategic HRM practice as compared with foreign owned MNEs operating in Australia. This may suggest, in the Australian context, a convergence of strategic HRM practice across MNEs.

HRM shared service centres were also considered. These centres allow corporate services to be provided across an organisation (or part of) from a centralised unit. They are typically used in the provision of routine HRM functional processes such as recruitment administration and/or payroll though their nature can vary from organisation to organisation. Along with human resource information systems (HRIS) they promise economies of scale and specialisation as activities can conducted from a single location. Edwards et al. (2007) note that the use of cross-country shared services centres provide an indicator of the extent to which the HRM function is integrated across countries. Relative to foreign owned MNEs (37\%), Australian MNEs (72.5\%) are heavy users of these centres as evidenced by statistically significant proportion differences using Cramer's V tests $(C V=.277 ; \mathrm{p}<.01)$. Across each substantive country of origin, Australian MNEs exhibited the highest use. This finding indicates that further research is required to examine why this should be the case.

Finally, we look at the use of HRIS that cover the worldwide organisation, i.e. information systems that hold data relating to the firm's international workforce. We found statistically significant proportional differences at a 10 per cent confidence level using Cramer's V tests $(C V=.125 ; \mathrm{p}<.10)$. Sixty per cent of MNEs indicated their use which broke down into sixty-three per cent of foreign firms and 48 per cent of Australian MNEs.

\section{Pay and Performance management (PPM)}

US MNEs have long been regarded as HRM innovators in such aspects of PPM as productivity-related pay bargaining, individual performance appraisal, performance-related pay, employee share ownership and profit sharing (e.g. Ferner and Almond, 2013).

In figure 1, we find that 15 per cent of all US MNEs aim to pay in the first or second quartile of the relevant pay distribution for their LOG, 30 per cent in the first or second 
quintile for the key group of employees and 25 per cent for their managers. Results for Australian, UK and Japanese owned MNEs are similar. The most notable difference appears in respect to the Asian MNEs but given that this is quite a disparate category we urge caution in making interpretations. By some distance Asian MNEs are the most likely to have a pay policy for all employee categories that are linked to the top or second quartile.

\section{Figure 1 here}

The vast majority of companies have formal performance appraisal systems schemes for employees in Australia. Comparing Australian and foreign-owned MNEs we can see that all domestic MNEs have a formal performance appraisal for managers and the key group and almost 90 per cent for the LOG. Almost 98 per cent of foreign MNEs reported formal appraisals for their managers, 96 per cent of those recognising a key group stated they had a formal appraisal while 90 per cent have one for the LOG.

In terms of forced distribution (FD) appraisal systems figure 2 shows that one third of MNEs reported the use of FD for managers, 34 per cent for the key group and 27 per cent for the LOG. The results by country of origin again provide an unexpected Asian MNE result in that there was high use of FD, particularly with respect to the LOG. Australian MNEs were found to be relatively low users of FD appraisal across all employee categories including managers. A closer look at the types of performance appraisal systems suggests that both foreign and domestic MNEs have commonly adopted single integrated appraisal systems, i.e. the same appraisal scheme is used for the different categories of employees.

Figure 2 here

With respect to the use of 360-degree appraisals, it was not unexpected to see that managers are the most likely to receive this form of appraisal. Some 56 per cent of all MNEs reported that they provide 360-degree feedback to managers, 39 per cent do so in respect to the key group while only 28 per cent provide such feedback to the LOG. Australian MNCs appear as low users of 360 degree appraisal systems, especially for LOG and key group employees (figure 3). Overall, Australian MNEs tend to be relatively low users of formal performance appraisal systems for the LOG and key employees. This is another area for further investigation (see Bartram et al 2015).

Figure 3 here

Notwithstanding the above findings for the LOG, turning to performance related pay, the breakdown by country of origin (see figure 4) is relatively similar (we ran Cramer's V tests and found no significant differences among the three categories of employee responses concerning performance related pay). However, the MNEs across the nine country cohorts including Australia (85.7 per cent for Key Groups and 95 per cent for Managers) were generally high users of PRP for the Key Group and Managers. Considering the evidence that suggests US firms introduced the use of linking pay to performance, one may have expected a greater percentage of US MNEs to report a variable pay element for the LOG. It may be that the LOG across all operations in Australia is governed by collective agreements and awards that limit the scope for individualised pay systems.

Figure 4 here 
Figure 5 shows the breakdown for the use of employee share ownership schemes (ESOS) in Australia according to the country of origin of the MNE. Based on Cramer's V tests we can report that there were statistically significant proportion differences among the three categories of employee responses concerning ESOSs: LOG $(\mathrm{CV}=.378 ; \mathrm{p}<.01)$; Key $(\mathrm{CV}=.451 ; \mathrm{p}<.01)$; and Managers $(\mathrm{CV}=.413 ; \mathrm{p}<.01)$. The findings demonstrate that Australian, UK and French MNEs are the highest users of ESOS for the LOG. For example, 51 per cent of Australian MNEs used ESOSs for their LOG as compared with 24.7 per cent of US MNEs. For the Key Group a similar pattern emerged with Australian, UK and French MNEs among the highest users of ESOS. For the Managers, Australian MNEs were the highest users of ESOS. Again, this is an interesting finding and may reflect the ownership structure of Australian MNEs that was previously noted, namely they are largely publically listed companies.

\section{Figure 5 here}

Turning to the provision of profit sharing for the LOG, the key group and managers in Australia (see Figure 6), there tends to be less use of such arrangements when compared with ESOSs. There were no statistical significant proportion differences among the three employee categories by country of ownership. However, interestingly for the LOG 'the Rest of the World' MNEs were the highest users of profit sharing followed by French, UK and then US MNEs. Moreover, for the Key Group of employees French MNEs followed by 'the Rest of the World' category and then the US MNEs were highest users of profit sharing. In terms of Managers we found that the 'Rest of the World' category followed by Asian, UK and French MNEs were the highest users of profit sharing. Overall, Australian MNEs were relatively low users of profit sharing schemes with the exception of profit sharing for managers.

\section{Figure 6 here}

\section{Employee Representation}

We also asked about the total number of employees in their Australian operations that were members of a trade union. The mean response was 18 per cent which is well above the average density for the private sector in Australia (12 per cent) (Brigden, 2012). US MNEs reported the lowest union membership density (9.98\%), UK MNEs reported a relatively lowdensity rate (12.88\%). Australian and Japanese MNEs had higher reported rates union density rates at $20.25 \%$ and $22.93 \%$ respectively.

We also report union recognition by MNEs in their Australian operations in terms of their country origin in figure 5. That is, for bargaining purposes did the MNE recognise a trade union? We use a dichotomous variable whereby the MNE does not recognise unions or they recognise them at one or more sites. A higher percentage of 'Rest of Europe MNEs' category, German, Australian and French MNEs report trade union recognition relative to British, Japanese and US MNEs. This was borne out in statistically significant proportion differences using Cramer's V tests $(\mathrm{CV}=.271 ; \mathrm{p}<.10)$.

Overall, Australian MNEs were more likely than US and UK MNEs to recognise trade unions for bargaining purposes. They also reported much higher trade union density rates than the mean for all MNEs and for the national average. Once again this is an issue that requires further examination and has implications for the nature of the bargaining and the bargaining arrangements undertaken at the workplace. 
Figure 7 here

\section{Succession Planning}

Succession planning involves the formal and systematic identification and development of an organisation's workforce and is typically focused on senior management succession. Figure 8 demonstrates that a substantial number of foreign owned and Australian owned MNEs have a formal system of succession planning for their senior managers. However, around one quarter of foreign and Australian owned MNEs have no formal system of succession planning in place for their senior managers in their Australian operations.

\section{Figure 8 here}

Keeping on the theme of succession, we asked respondents to indicate, using a fivepoint Likert scale, the extent to which internal promotion is favoured over external managerial recruitment. An independent-sample t-test was carried out to compare results between foreign and Australian owned MNEs. Results showed that there were no significant difference in the way internal promotion was favoured in foreign $(M=4.13, S D=.85)$ and Australian MNCs $(M=4.05, S D=.904) ; t(209)=.56, p=.58$ (two-tailed).

Regarding MNEs staff development programs, a large number of foreign owned (67.8\%) and Australian owned MNEs (67.5\%) reported the use of formal development programme aimed at developing employees with high potential in all of their Australian operations.

We then compared how extensively various techniques were used for the development of high potential employees in the Australian operations through an independent-sample t-test. Respondents were asked to use a five-point Likert scale ranging from 'not used at all' to 'used very extensively'. There was no significant difference in the way short term international assignments have been used for the development of high potentials in the Australian operations of foreign MNCs $(M=2.48, S D=.98)$ and Australian owned MNEs $(M=2.47, S D=.95) ; t(169)=.07, p=.95$ (two-tailed). A significant difference was reported for formal global management training between foreign owned MNEs $(M=2.99, S D=1.08)$ and Australian owned MNEs $(M=2.47, S D=1.19) ; t(44)=$ 2.28, $p=.03$ (two-tailed). No significant difference was found for assessing performance against global management competencies for foreign owned MNEs $(M=3.21, S D=1.33)$ and Australian owned MNEs $(M=2.91, S D=1.38) ; t(169)=1.15, p=.25$ (two-tailed).

\section{Discussion and conclusions}

Australian MNEs are comparatively recent entrants into the international economy. It appears that given their dynamism and growing influence in the world economy further research is warranted to provide continued and further insights into their human resource management practices in Australia and overseas. Indeed, there is a strong need for greater focus on MNEs from small economies. This is one of a few studies to document the profile of Australian owned MNEs, their HRM practices in Australia and comparing such practices to foreign owned MNEs operating in Australia. However, this paper only provides descriptive data and there is a need for more in-depth analysis which will allow determinations to be made over the appropriateness of existing theoretical frameworks for MNEs from small and relatively recently internationalised economies. A key aim of this paper was, through the comparative process, to delineate some of the key characteristics of Australian owned MNEs so as to raise the point that they are worthy of investigation.

Based on the data provided here, it can be surmised that in general Australian owned MNEs have some differences with foreign MNEs operating in Australia. Our results suggest 
that there is some evidence that HRM in Australian MNEs has some degree of sophistication. While such a view would be at odds with Walsh (2001) and McGraw and Harley (2003) who argued that the HRM practices of Australian companies were less sophisticated than their overseas counterparts, it would support that of De Cieri and Dowling (1997) who suggested that there was increasing sophistication of HRM in Australian organisations and especially amongst Australian MNEs. The evidence presented here also indicates that across many of the HRM practices examined it is clear that Australian owned MNEs utilise similar programs to those found in foreign owned MNES operating in Australia. This finding supports Ferner and Almond's (2013) concept of MNE 'norms' that are the result of the influence of US practices. This suggests that there is evidence of convergence of most HRM practices in the operations of MNEs in Australia.

It is however not possible at this juncture, based on the descriptive analysis undertaken, to report whether there is a discernible Australian approach to HRM in respect to the indigenous MNEs. It would be interesting to also have included domestic only firms to establish if there are differences in the practices of Australian owned MNEs and Australian, domestic only firms. We do not know if there is an 'Australian' approach to HRM based on our particular administrative heritage and institutional context. The analysis is also confined to MNE practices in Australia with only limited reference to HRM practices of Australian MNEs offshore. As a cross sectional study the analysis cannot inform us about the changes that are occurring in HRM practices.

A particularly noteworthy finding was the high utilisation of HRM shared service centres compared to foreign owned MNEs. It is often reported that the idea of shared service centres emanated from the US yet here we have a finding whereby Australian MNEs are more likely to establish such structures. Research that looks to the reasons behind what appears to be relatively high use in Australian MNEs would be useful, as well as establishing the activities they carry out and the effectiveness of these centres. There is one particular question that would have merit; does the use of HRM shared service centres lead to a more strategic role for the HR function within organisations?

There were some noteworthy findings around pay and employee representation. Australian MNEs tend to have high use of employee share ownership schemes. Australian MNEs are also conceived as relatively low users of performance related pay for the LOG, but are high users of such practices for the key group and managerial employees; and they tend to be low users across all employee groups of forced distribution and 360 degree appraisal systems. Australian researchers have asserted that the conciliation and arbitration system of Australia has played a large role in constraining the scope for organisational autonomy and managerial discretion over their pay policy and practice (Bartram et al. 2015b). Despite the evolution towards decentralised bargaining and individual agreements (Lansbury and Michelson 2003; Townsend et al, 2013), there remains the core of centralised and collective institutions regulating work and workplaces. These institutions still have an important influence on pay and employment conditions of employees in Australia (Bailey and Peetz, 2013; Walsh, 2001) and this may explain the somewhat lower propensity to implement pay for performance for the employees in Australian owned MNEs. Australian MNEs generally had higher rates of unionisation as compared with American, European, and British counterparts. This may also have an impact on some of the pay and performance practices, and on the form of agreement making undertaken at the workplace (Bartram et al 2015b).

Despite, the growth of decentralisation and individualisation of the Australian industrial relation system which can be linked to a more neo-liberal political agenda in recent decades (Peetz, 2007), it appears from our research that the collective institutions still influence the management practice of MNEs, especially Australian MNEs. In some respects Australian MNEs use of HRM are similar to their foreign counterparts operating in Australia, 
but there remain important differences particularly in relation to industrial relations, and pay and performance management. This descriptive analysis cannot answer the questions around convergence versus divergence in HRM practices, nor can it identify what Australian (host) institutions and regulations shape the development and implementation of HRM practices in Australia and by Australian owned MNEs. However, there is sufficient evidence to indicate that the role of the industrial relations system and structure of corporate ownership warrants further investigation (Bartram et al, 2015a).

In terms of theorising the paper does not provide evidence on the determinants of the HRM practices in Australian operations nor does it indicate why there are deviations between Australian and foreign owned MNEs with respect to their HRM practices in Australia. As for the practice of HRM we can suggest here that the HRM practices of overseas owned and Australian MNEs are in the main similar and reflect a general convergence. However, since the study does not encompass non MNE firms we cannot indicate whether MNEs have more sophisticated and extensive HRM practices than domestic non MNE firms (Walsh, 2001).

This paper represents a rare snapshot of Australian MNEs at one point in time, and offers new insights into their characteristics and HRM practices within the Australian context. We encourage further research into Australian owned MNEs including extending into their international subsidiary operations (Kim and Gray, 2005) and an update of the survey of MNE operations in Australia to encompass the shift away from traditional source countries (USA and Europe) towards Asia, Canada and India. Further research could examine the HRM practices of Australian MNEs abroad, examine the changes in the HRM practices of Australian MNEs through time and examine the HRM policies and practices of Australian MNEs and Australian non MNE organisations.

\section{References}

Almond P, T Edwards, T Colling, A Ferner, P Gunnigle, M Muller-Camen, J Quintanilla and H Waechter (2005) Unravelling Home and Host Country Effects: An investigation of the HR policies of an American multinational in four European countries. Industrial Relations 44, 276-306.

Australian Bureau of Statistics (2011) Catalogue 5352.0. International Investment Position, Australia.

Akhtar RS, ZD Ding and GL Ge (2008) Strategic HRM Practices and Their Impact on Company Performance in Chinese Enterprises. Human Resource Management 47, 1532.

Bartram T, B Boyle, P Stanton, J Burgess and A McDonnell (2015a) Multinational companies and industrial relations: A research agenda for the 21st century. Journal of Industrial Relations 57(2), 1-19.

Bartram T, B Boyle, P Stanton, G Sablock, and J Burgess (2015b) Performance and Reward Pratices of multinational companies operating in Australia Journal of Industrial Relations 57(2), 210-231.

Björkman I and JE Lervick (2007) Transfering HRM Practices within Multinational Entreprises. Human Resource Management Journal 17, 320-335.

Boxall P and J Purcell (2008) Strategy and human resource management. Basingstoke and New York: Palgrave Macmillan.

Brigden C (2012) Unions and Collective Bargaining in 2011. Journal of Industrial Relations 54(3), 361-376. 
Colling T, and Clark I (2002) Looking for Americanness': Home-country, sector and firm effects on employment systems in an engineering services company. European Journal of Industrial Relations 8(3), 301-324.

De Cieri H and PJ Dowling (1997) Strategic International Human Resource Management. Management International Review 37, 21-42.

Dick, H. and Merrett, D. (2007), Introduction. In Dick, H. and Merrett, D. The Internationalisation Strategies of Small Country Firms: the Australian Experience of Globalisation. Edward Elgar, Cheltenham, 3-17

EdwardsP, O Tregaskis, R Sánchez-Mangas, C Levesque, A McDonnell and J Quintanilla (2013) Human resource practices in the multinational company: A test of system, societal and dominance effects, Industrial and Labor Relations Review 66(3), 588615.

Edwards, TJ, P Marginson and AM Ferner (2013) Multinational Companies in CrossNational Context: Integration, Differentiation and the Interactions between MNCs and Nation States. Industrial \& Labor Relations Review 66(3), 547-587.

Edwards P, T Edwards, A Ferner, et al. (2007) Employment practices of MNCs in organisational context: A large-scale survey. De Montfort University.

Farndale E, C Brewster, and E Poutsma (2008) Coordinated Vs. Liberal Market HRM: The Impact of Institutionalization on MNEs. The International Journal of Human Resource Management 19, 2004-2023.

Fee, A., McGrath-Champ, S. and Yang, X. (2011), Expatriate performance management and firm internationalization: Australian multinationals in China. Asia Pacific Journal of Human Resources. 49, 3, 365-384.

Fenton-O’Creevy M, P Gooderham, and O Nordhaug (2007) HRM in US subsidiaries in Europe and Australia. Journal of International Business Studies 39(1), 151-66.

Ferner AM and P Almond (2013) Performance and reward practices in foreign multinationals in the UK. Human Resource Management Journal 23(3), 241-261.

Ferner AM and Quintanilla J (2002) Between globalization and capitalist variety: multinationals and the international diffusion of employment relations. European Journal of Industrial Relations 8(3), 243-50.

Foreign Investment Review Board (2014) Annual Report 2013-2014. Canberra.

Gooderham P, O Nordhaug, and K Ringdal (2006) National embeddedness and calculative human resource management in US subsidiaries in Europe and Australia Human Relations, 59, 1491-1513.

Gooderham, P and O Nordhaug (2010) One European Model of HRM? Cranet Empirical Contributions. Human Resource Management Review 21, 27-36.

Guest DE, and K Hoque (1996) National ownership and HR practices in UK greenfield sites. Human Resource Management Journal 6(4), 50-74.

Hall PA and DW Soskice (2001) Varieties of capitalism: The institutional foundations of comparative advantage. Oxford: Oxford University Press Hall.

Haiying $\mathrm{K}$ and Shen J (2014). International human resource management policies and practices of South Korean MNEs: a review of the literature, Asia Pacific Business Review 20, 42-58.

Hutchings, K. (1996), Workplace Practices of Australian and Japanese MNEs Operating in Singapore, Malaysia and Indonesia. Human Resource Management Journal. 6, 2, 5871

Hutchings, K. (2005), Koalas in the land of the pandas: reviewing Australian expatriates' China preparation. The International Journal of Human Resource Management . 16, 4, 533-566. 
Johnston S, and B Menguc (2007) Subsidiary size and the level of subsidiary autonomy in multinational corporations: A quadratic model investigation of Australian subsidiaries. Journal of International Business Studies 38(5): 787-801.

Kim, Y and SJ Gray (2005) Strategic factors influencing international human resource management practices: An empirical study of Australian multinational corporations, International Journal of Human Resource Management 16(5), 308-324.

Kramar R and E Parry (2014) Strategic human resource management in the Asia Pacific region: Similarities and differences? Asia Pacific Journal of Human Resources 52(4), 400-419.

Kuhlman, T. and Hutchings, K. (2010), Expatriate assignments vs localization of

Management in China: Staffing choices of Australian and German companies. Career

Development International. 15, 1, 20-38.

Lansbury R and G Michelson (2003) Industrial Relations in Australia. In Ackers P and A Wilkinson. Understanding Work and Employment. Oxford University Press, Oxford, 227-242.

McDonnell A, J Lavelle and P Gunnigle (2014) Human Resource Management in Late Industrialising Economies: Evidence from Ireland, Management International Review 54(3), 361-380.

McDonnell A, P Stanton, and J Burgess (2011a), Multinational enterprises in Australia: Two decades of international human resource management reviewed. Asia Pacific Journal of Human Resources 49, 9-35.

McDonnell A, H Russell, G Sablok, P Stanton, J Burgess, and T Bartram (2011b)Methodology and research on human resource practices of multinational enterprises in Australia', Australian Bulletin of Labour 37(2), 230-245.

McGraw P (2014) Changing patterns of compensation and benefits in multinational and Australian companies 1996-2009, Asia Pacific Journal of Human Resources, doi: 10.1111/1744-7941.12040

McGraw P (2002) The HR function in local and foreign firms: Evidence from the Pricewaterhouse Coopers-Cranfield HR Project, Asia Pacific Journal of Human Resources 40(2), 205-227.

McGraw P and Harley B (2003), Industrial Relations and Human Resource Management Practices in Australian and Overseas-owned Workplaces: Global or Local? Journal of Industrial Relations 45 (1), 1-22.

Merrett, D. (2007), Australian Multinationals in Historical Perspective. Do You Come from the Land Down Under? In Dick, H. and Merrett, D. The Internationalisation Strategies of Small Country Firms: the Australian Experience of Globalisation. Edward Elgar, Cheltenham, 18-36.

Peetz D (2007) Assessing the impact of WorkChoices One Year On. Report to Department of Innovation, Industry and Regional Development, Melbourne.

Purcell W, Nicholas S, Merrett D and Whitwell G (1999) The transfer of human resource and management practices by Japanese multinationals to Australia: do industry, size and experience matter? International Journal of Human Resource Management 10, 72-88.

Sidani Y and A Al Ariss (2014). Institutional and Corporate Drivers of Global Talent Management: Evidence from the Arab Gulf Region. Journal of World Business, 49, 215-224. 
Tharenou, P. and Harvey, M. (2006), Examining the overseas staffing options utilized by Australian headquartered multinational corporations. The International Journal of Human Resource Management. 17, 6, 1095-1114.

Townsend K, A Wilkinson and J Burgess (2013) Is Enterprise Bargaining Still a Better Way of Working? Journal of Industrial Relations 55, 100-117.

UNCTAD (2012) World Investment Report 2012. New York.

Walsh J (2001) Human resource management in foreign-owned workplaces: Evidence from Australia. International Journal of Human Resource Management 12(3), 435-44.

Zalan T and G Lewis (2006) Administrative Heritage: An exploratory study of Large Australian Firms. Australian Journal of Management 31(2) 293-311. 
Table 1: MNEs in Australia

\begin{tabular}{cc}
\hline Country of origin & Number of MNEs in Australia \\
\hline US & 407 \\
Australia & $168(16.7 \%)$ \\
UK & 90 \\
Japan & 71 \\
Germany & 49 \\
France & 39 \\
Nordic & 26 \\
Asia & 54 \\
Rest of world & 44 \\
Rest of Europe & 60 \\
Total & 1008 \\
\hline
\end{tabular}

Table 2: Primary Sector of Australian and Foreign MNEs in Australia

\begin{tabular}{ccc}
\hline Sector & $\begin{array}{c}\text { Australian } \\
\mathbf{\%}(\mathbf{N = 4 0 )}\end{array}$ & $\begin{array}{c}\text { Foreign } \\
\mathbf{\%} \text { (N=171) }\end{array}$ \\
\hline Mining & 7.5 & 7 \\
Utilities & - & 1.8 \\
Manufacturing: food/beverages, clothing, paper etc & 7.5 & 9.9 \\
Manufacturing: engineering, computers etc & 10.0 & 13.5 \\
Manufacturing: chemicals, pharmaceuticals & 5.0 & 9.9 \\
Services: financial \& business services & 25.0 & 18.7 \\
Services: ICT & 15.0 & 15.8 \\
Engineering services/ consultancy & 2.5 & 3.5 \\
Construction & 7.5 & 3.5 \\
Retail and Wholesale & 10.0 & 11.7 \\
Transport and Storage & 2.5 & 3.5 \\
Health & 7.5 & 1.2 \\
\hline
\end{tabular}

Table 3: MNE structures in Australia

\begin{tabular}{ccc} 
Division & $\begin{array}{c}\text { Australian } \\
\mathbf{\%}(\mathbf{N}=\mathbf{4 0})\end{array}$ & $\begin{array}{c}\text { Foreign } \\
\mathbf{\%} \text { (N=170) }\end{array}$ \\
\hline International product division & 75 & 85 \\
Regional division & 72.5 & 89 \\
Global business division & 55.5 & 85 \\
National subsidiary companies & 80.0 & 75 \\
& & \\
\hline
\end{tabular}


Table 4: Australian and Foreign MNEs Characteristics

\begin{tabular}{|c|c|c|}
\hline Characteristic & Foreign-owned MNCs & Australian-owned MNCs \\
\hline $\begin{array}{l}\text { Number of employees } \\
\text { worldwide }\end{array}$ & $\begin{array}{l}\text { Mean 66,226; 28,500 } \\
\text { median }\end{array}$ & Mean 24061; 7000 median \\
\hline $\begin{array}{l}\text { Number of employees in } \\
\text { Australia }\end{array}$ & Mean 1762; 500 median & Mean 16358; 4000 median \\
\hline $\begin{array}{l}\text { How many sites in } \\
\text { Australia }\end{array}$ & Mean 18; 6 median & Mean 321; 30 median \\
\hline $\begin{array}{l}\text { How many countries } \\
\text { operate in? }\end{array}$ & $\begin{array}{llr}2 \text { countries }-1 \% ; & 3-5 \\
\text { countries }-3 \% ; & 6-10 \\
\text { countries - } 10.5 \% ; & 11+ \\
\text { countries - 85.5\% } & \\
\end{array}$ & $\begin{array}{l}2 \text { countries }-10 \% \text {; } 3-5 \text { countries - } \\
27.5 \% \text {; } 6-10 \text { countries - } 22.5 \% \text {; } \\
11+\text { countries }-40 \%\end{array}$ \\
\hline Publicly traded company & $72.5 \%$ & $85 \%$ \\
\hline $\begin{array}{l}\text { Most important } \\
\text { good/service or brand. }\end{array}$ & $\begin{array}{l}\text { Adapted significantly to } \\
\text { national markets - } 31.5 \% \\
\text { Adapted to different regions } \\
\text { of the world but } \\
\text { standardised within them - } \\
41 \% \\
\text { Standardised globally - } 27 \% \\
\end{array}$ & $\begin{array}{l}\text { Adapted significantly to national } \\
\text { markets - } 37 \% \\
\text { Adapted to different regions of the } \\
\text { world but standardised within them } \\
-32 \% \\
\text { Standardised globally - 32\% }\end{array}$ \\
\hline $\begin{array}{l}\text { What strategy does the } \\
\text { MNC adopt to compete } \\
\text { internationally? }\end{array}$ & $\begin{array}{l}\text { Low cost standardisation } \\
\text { strategy - } 15 \% \text {. } \\
\text { Localisation strategy - } 25 \% \\
\text { Strategy design to } \\
\text { simultaneously achieve } \\
\text { localisation and low cost } \\
\text { global standardisation - } \\
41 \% \\
\text { Replication strategy to sell } \\
\text { products/services developed } \\
\text { at home market } \\
\text { internationally - } 19 \%\end{array}$ & $\begin{array}{l}\text { Low cost global standardisation } \\
\text { strategy - 19\%. } \\
\text { Localisation strategy - 35\% } \\
\text { Strategy design to simultaneously } \\
\text { achieve localisation and low cost } \\
\text { global standardisation - 30\% } \\
\text { Replication strategy to sell } \\
\text { products/services developed at } \\
\text { home market internationally - 16\% }\end{array}$ \\
\hline 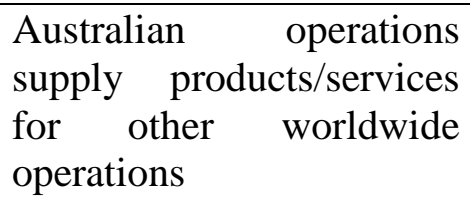 & $53 \%$ & $74 \%$ \\
\hline $\begin{array}{l}\text { Worldwide operations } \\
\text { supply products/services } \\
\text { to Australian operations }\end{array}$ & $79 \%$ & $50 \%$ \\
\hline $\begin{array}{l}\text { When were the Australian } \\
\text { operations established? }\end{array}$ & Mean 1967; 1976 median & Mean 1942; 1966 median \\
\hline $\begin{array}{l}\text { When did the current } \\
\text { ultimate controlling } \\
\text { company establish in } \\
\text { Australia? }\end{array}$ & Mean 1976; 1986 median & Not applicable \\
\hline
\end{tabular}



\begin{tabular}{|l|l|ll|}
\hline $\begin{array}{l}\text { How did you develop your } \\
\text { first overseas operation? }\end{array}$ & $\begin{array}{l}\text { Greenfield, 47\%; M\&A, } \\
49 \% \text {; other 4\% }\end{array}$ & $\begin{array}{l}\text { Greenfield, 40\%; M\&A, 57.5\%; } \\
\text { other 2.5\% }\end{array}$ & \\
\hline
\end{tabular}

Variable N ranging from 146-171 (Foreign MNEs); 35-40 (Australian MNEs) 
Figure 1 Pay rate policy by country of origin for Australian operations

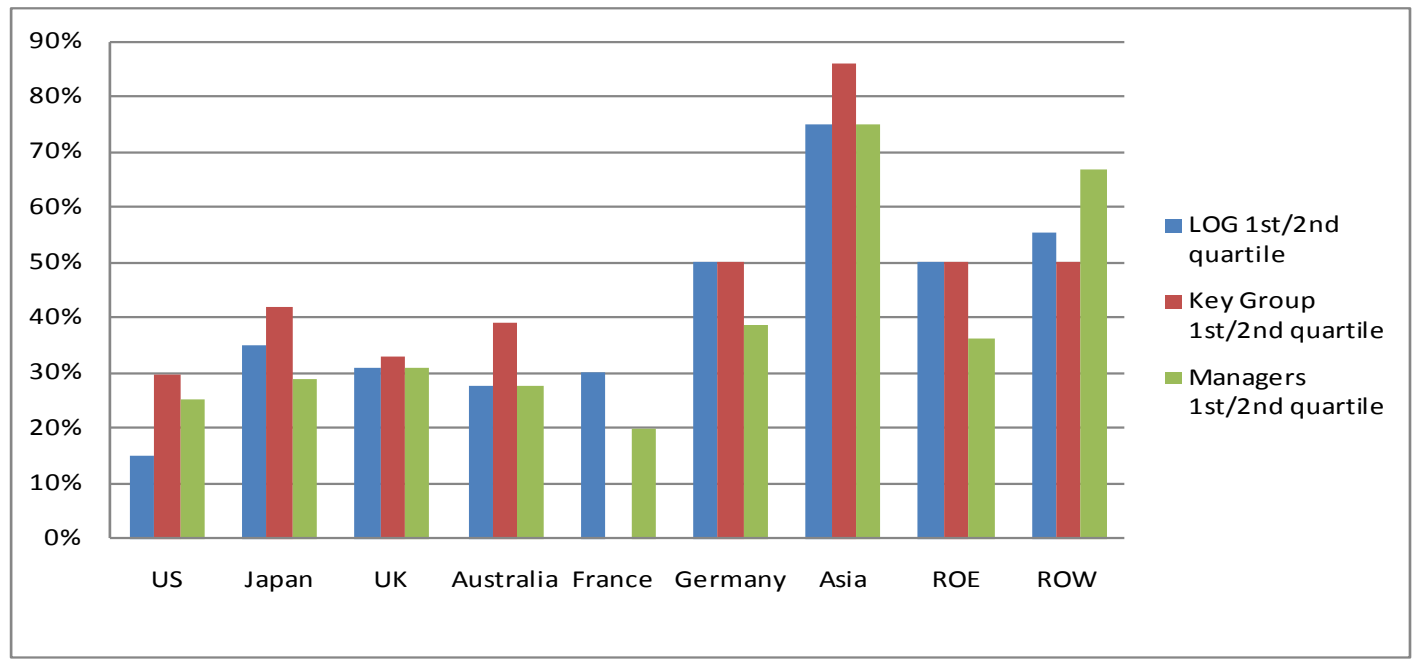

N = 207 (LOG); 125 (key group); 208 (managers)

Figure 2: Forced distribution for the LOG, key group \& managers by country of origin in Australian operations

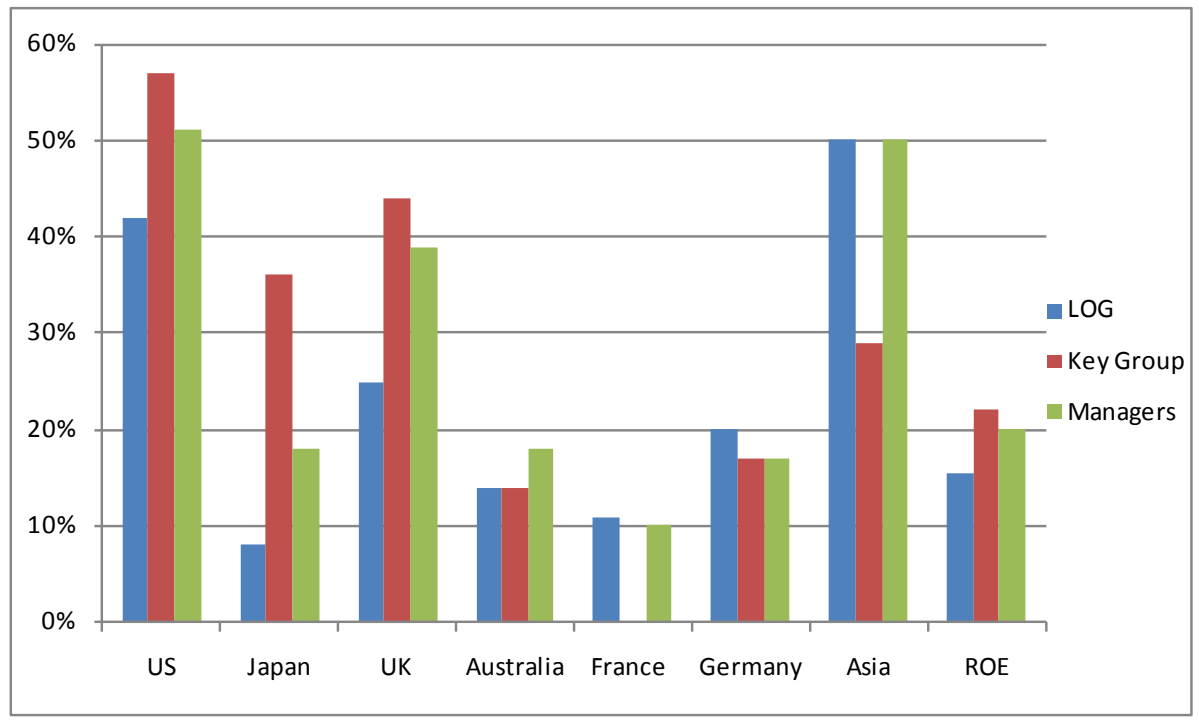

$\mathrm{N}=173$ (LOG); 121 (key group); 208 (managers) 
Figure 3: 360-degree appraisals by employee group by country of origin for Australian operations

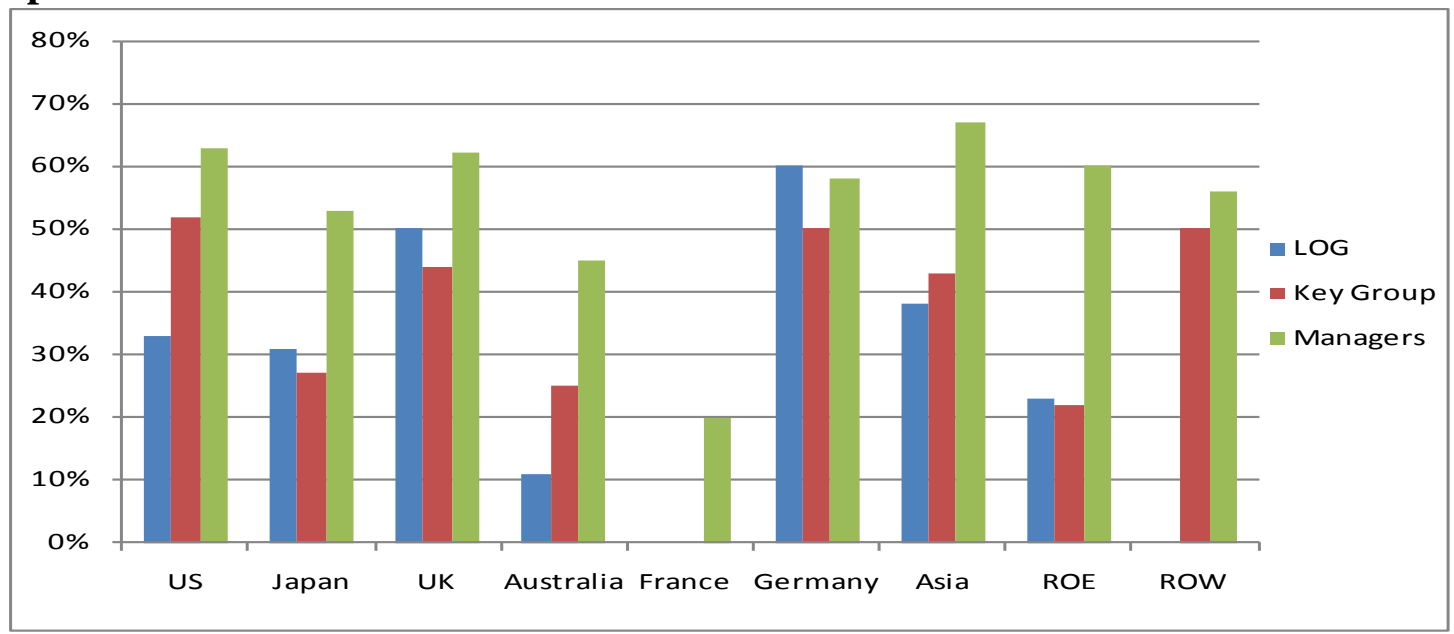

N = 173 (LOG); 121 (key group); 208 (managers)

Figure 4 Performance related pay - LOG, key group \& managers by country of origin for Australian operations

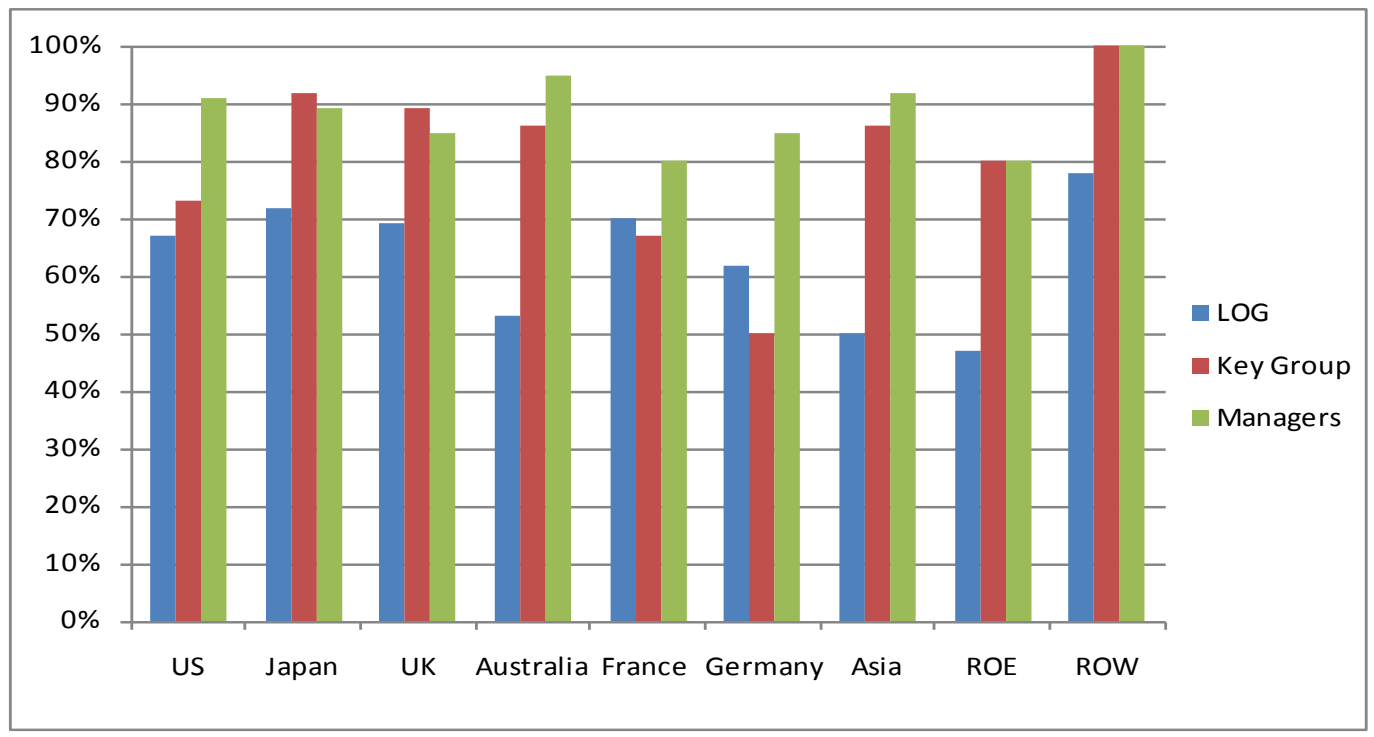

$\mathbf{N}=211$ (LOG and managers); 125 (key group) 
Figure 5 Employee share ownership schemes by employee group and country of origin in Australian operations

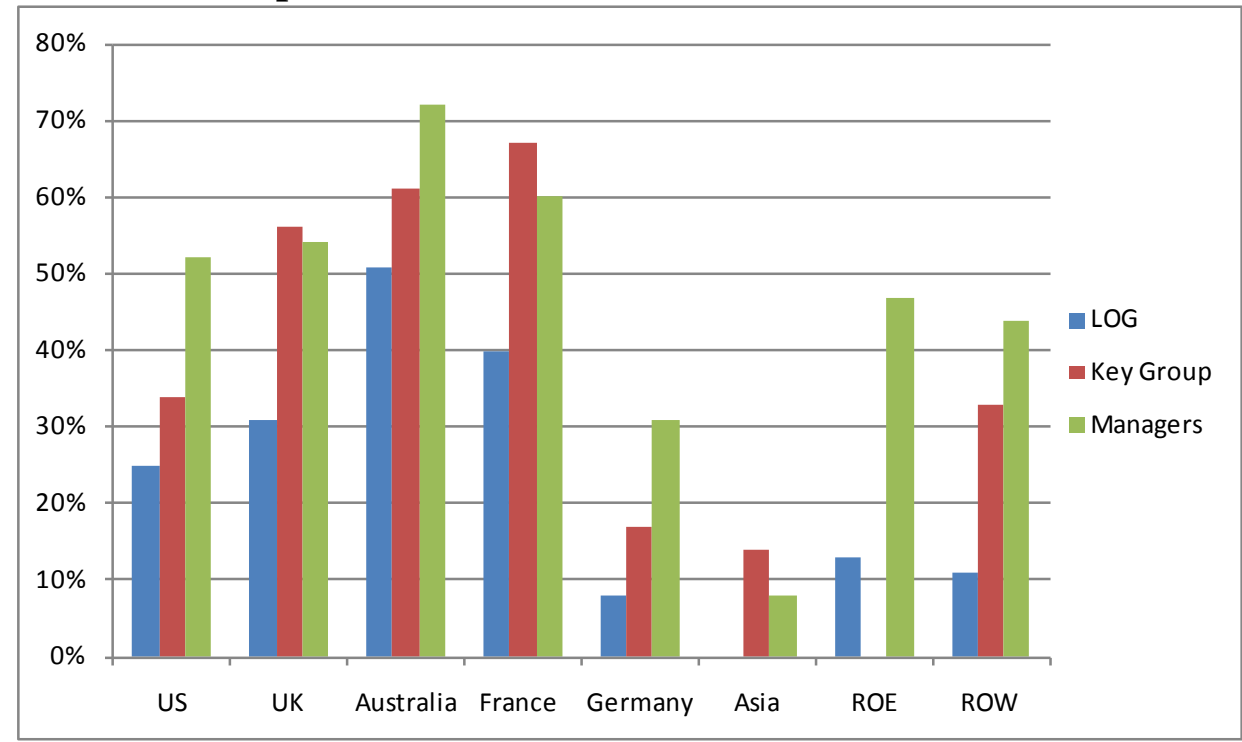

$\mathrm{N}=210$ (LOG and managers); 125 (key group)

Figure 6 Profit sharing by employee group and country of origin in Australian operations

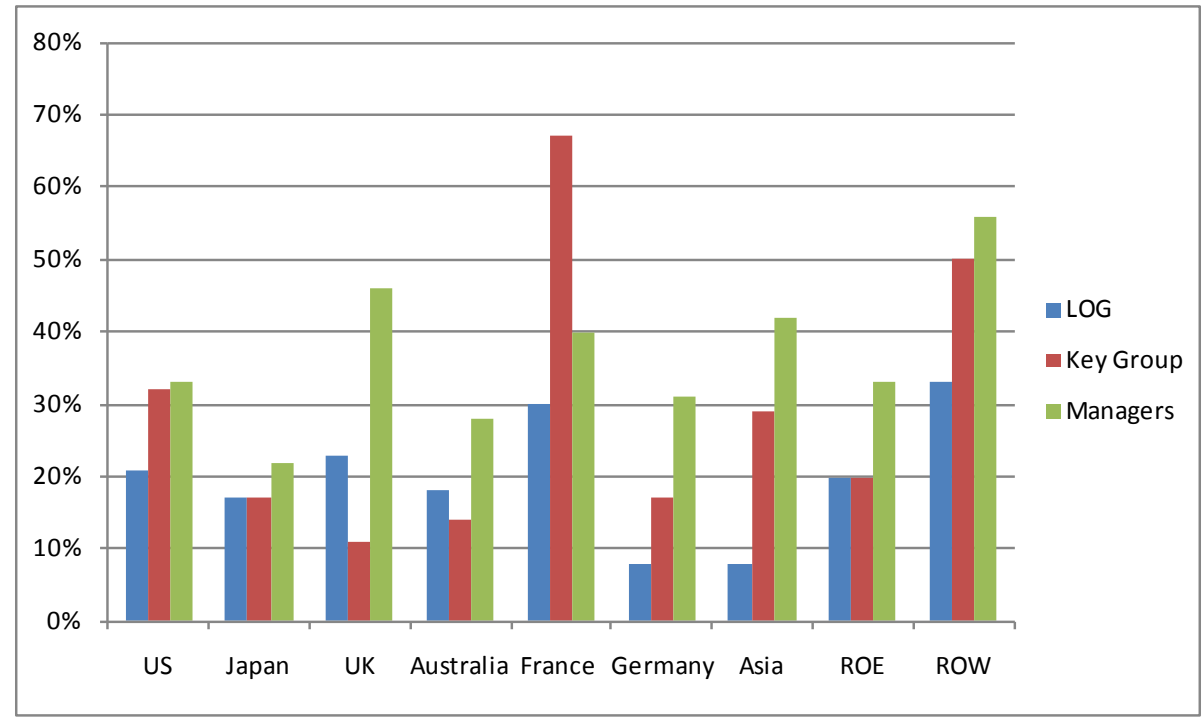

$\mathrm{N}=211$ (LOG and managers); 125 (key group) 
Figure 7 Trade union recognition by country of origin in Australian operations

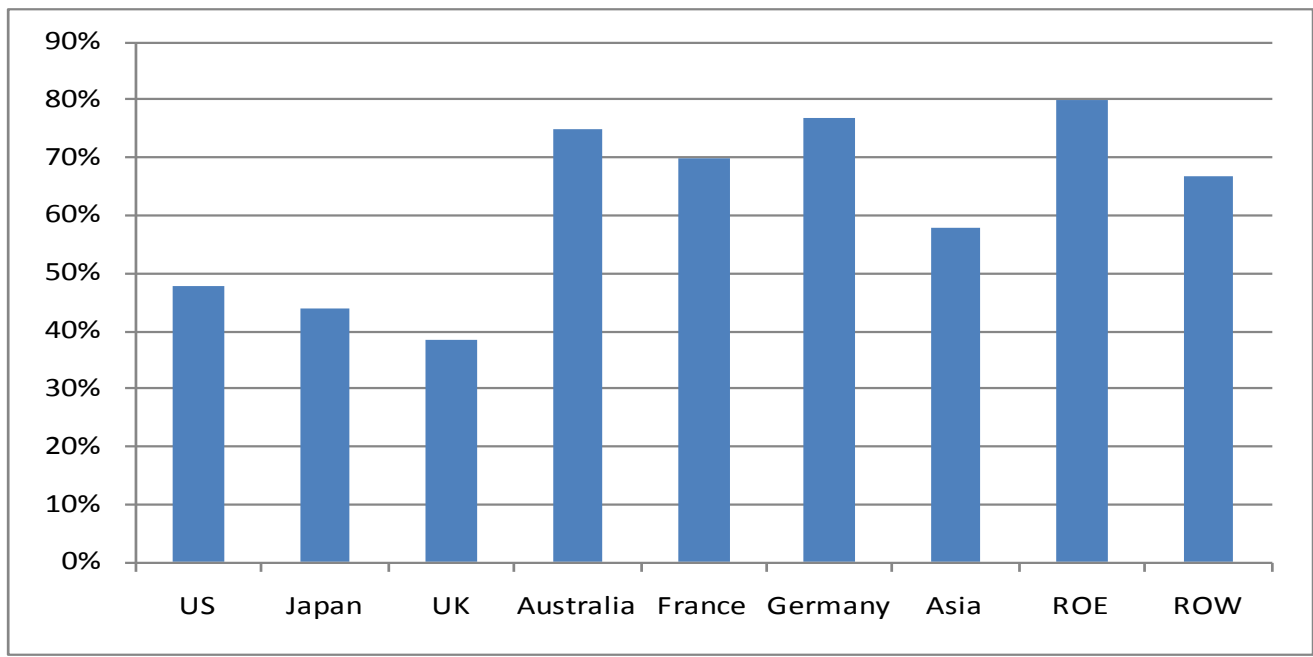

$\mathbf{N}=211 ; \mathrm{ROE}$ - rest of Europe; ROW - rest of world

Figure 8 Succession Planning in Foreign and Australian Owned MNEs in Australia

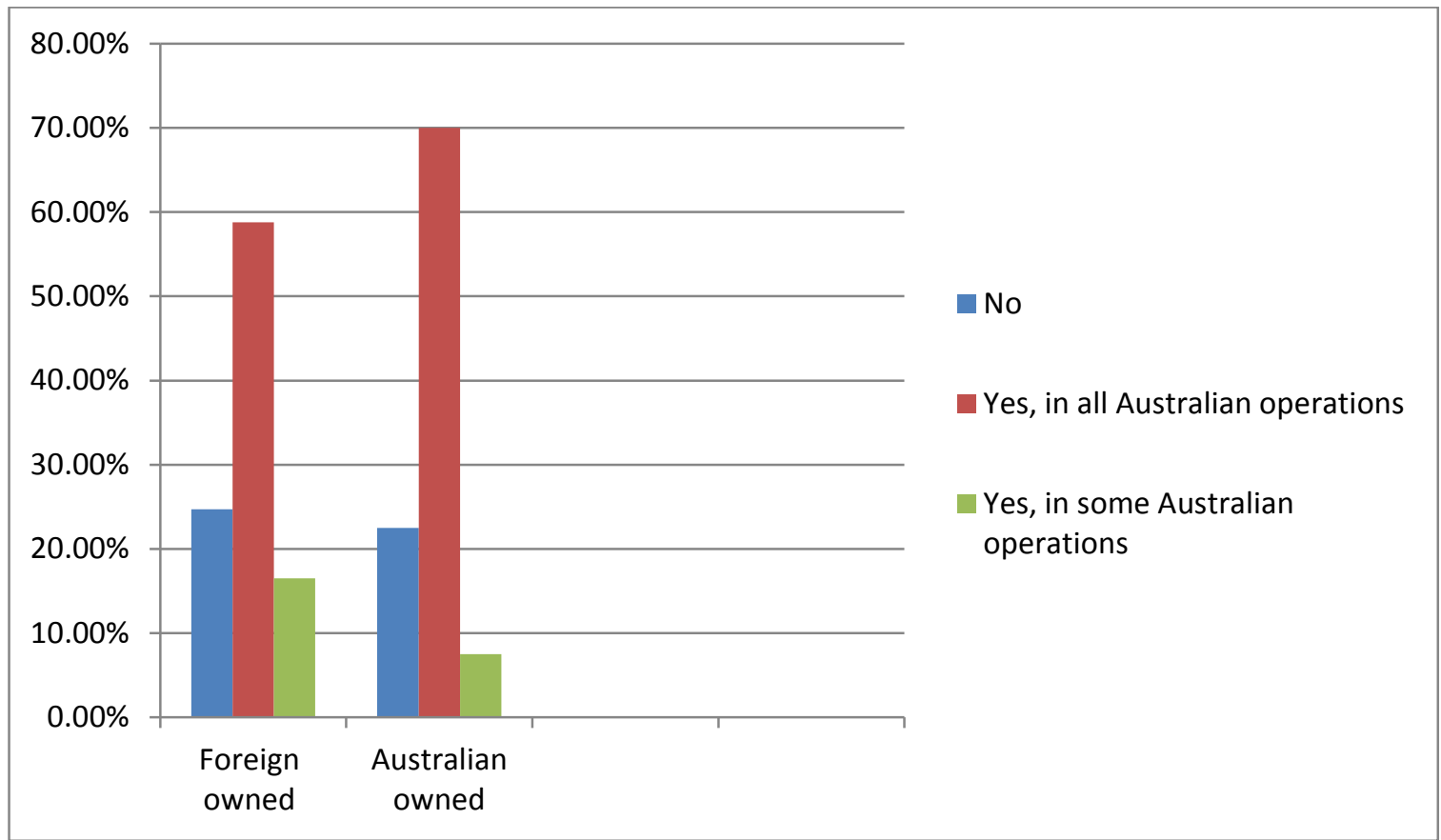

$\mathbf{N}=211$ 